\title{
Homenagem a Clara Mafra
}

\author{
Ruy Blanes \\ Instituto de Ciências Sociais da Universidade de Lisboa / \\ Universidade de Bergen \\ Lisboa/Bergen - Portugal/Noruega
}

Eu conheci a Clara há muitos, muitos anos, quando ela estava em Lisboa a visitar

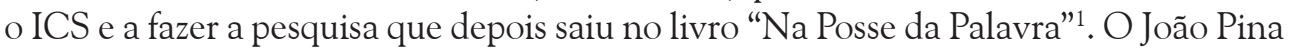
Cabral, meu orientador, pôs-me em contato com ela porque eu começava a estudar os evangélicos ciganos e pensava que poderia aprender muito com ela. E de facto assim foi. Ainda me lembro da sua paciência ao passar uma tarde inteira comigo ouvindo as minhas ideias incoerentes e procurando encontrar pistas para desenvolver o trabalho. Àquela altura, eu ainda não tinha começado o meu terreno e estava muito preocupado com a questão do proselitismo em contexto pentecostal, e ela soube desmistificar e desconstruir a questão de uma forma espetacular para mim. Foi o início de um debate que desembocou num artigo que publiquei anos depois na Social Anthropology.

A partir daí, sempre acompanhei o trabalho dela com grande interesse, em particular as suas ideias sobre o transnacionalismo evangélico no espaço lusófono e os seus textos sobre templos e arquiteturas religiosas, que me influenciaram bastante em diversos momentos.

Assim, foi sempre uma alegria poder continuar os contatos, em particular quando ela e o Ramon começaram a fazer equipe e a Claudia veio para Lisboa. Os projetos que tivemos juntos sobre Angola, que possibilitaram vários encontros entre os grupos de Lisboa e o Rio de Janeiro, foram oportunidades fantásticas de interagir com ela. No fundo, apesar dos contatos que mantenho com muitos colegas no Brasil, a Clara era sempre o ponto de referência no que diz respeito à antropologia brasileira.

Finalmente, foram a Clara e a Claudia que tornaram possível que eu pudesse visitar o Rio de Janeiro pela primeira vez, em novembro de 2012. Aí, desconhecendo que a Clara já se encontrava doente, pude conhecê-la um pouco no seu ambiente acadêmico, e cheguei a comentar com o Ramon que, dentro do que me parecia ser um sistema muito hierarquizado e competitivo, a Clara parecia um raio de luz, alguém com uma humildade, boa disposição, bom senso e carinho inigualáveis. Senti-me com sorte de poder ser colega dela. E de repente, em questão de meses, ela nos deixou...

\section{Nota}

1 MAFRA, Clara. (2002), Na posse da palavra - religião, conversão e liberdade pessoal em dois contextos nacionais. Lisboa: Instituto de Ciências Sociais da Universidade de Lisboa. 